It is philosophical to infer from these observations that not only are the line and flutings in question produced by carbon, but that the bluc line (4266), since it is visible at the highest temperature, corresponds to the most simple molecular grouping we have reached in the expcriments, and the flutings to others more complex.

The result to which attention is most to be directed in this place is that touching the two sets of flutings, and should future research justify the double conclusion (I) that these flutings are truly due to carbon, a result I accept, though it is denied by Ångström and Thalèn; and (2) that the different flutings really represent the vibrations of different molecular groupings; a great step, and one in the direction of simplification, will have been gained.

Indeed it is much to be hoped that this ground will be at once worked over again by men of science who are both honest and competent : that the truth is sure to gain by such work is a truism.

I have so often taken occasion to refer with admiration to the work of Angström and Thalèn that I shall not be misunderstood when I say that their conclusions, to which such prominence is given, and on which such great stress is laid by Messrs. Liveing and Dewar, rest more upon theory and analogy than upon experiment.

Their work, undertaken at a time when the cxistence of so-called "double spectra" was not established upon the firm basis that it has now, and when there was $n_{O}$ idea that the spectrum recorded for us the results of successive dissociations, gave, as I have previously taken occasion to state, the benefit of the doubt in favour of flutings being due to compounds, and it was thought less improbable that cyanogen or acetylene should have two spectra than that carbon or hydrogen should possess them.

Indeed, later researches have thrown doubt upon the view that the fluted spectra of aluminium and magnesium arc entirely due to the oxides of those metals instead of to the metals themselves-and this is the very basis of the analogy which Angström and Thalèn employed.

The importance of the observations to which I have referred is all the greater because of the general conclusions touching other spectra which may be drawn from thcm. Thus from what $I$ have shown it will be clear that if my view is correct the conclusions drawn ${ }^{x}$ by Messrs. Liveing and Dewar from the assumed hydrogen-carbon bands touching both the spectrum of magnesium and the spectra of comets, are entirely invalid. These conclusions are best given in their own words :-

"The similarity in the character of the magnesiumhydrogen spectrum, which we have described, to the green bands of the hydrocarbons is very striking. We have similar bright maxima of light, succeeded by long drawn-out serics of fine lines, decreasing in intensity towards the more refrangible side. This peculiarity, common to both, impels the belief that it is a consequence of a similarity of constitution in the two cases, and that magnesium forms with hydrogen a compound analogous to acetylene. In this connection the very simple relation $(2:$ I) between the atomic weights of magnesium and carbon is worthy of note, as well as the power which magnesium has, in common with carbon as it now appears, of combining directly with nitrogen. We may

\footnotetext{
I Paper rcad February 12, I880.
}

with some reason expect to find a magnesium-nitrogen spectrum. . . .

"The interest attaching to the question of the constitution of comets, especially since the discovery by Huggins that the spectra of various comets are all identical with the hydrocarbon spectrum, naturally leads to some speculation in connection with conclusions to which our experiments point. Provided we admit that materials of the comet contain ready-formed hydrocarbons, and that oxidation may take place, then the acetylene spectrum might be produced at comparatively low temperatures without any trace of the cyanogen spectrum or of metallic lines. If, on the other hand, we assume only the presence of uncombined carbon and hydrogen, we know that the acetylene spectrum can only be produced at a very high temperature, and if nitrogen werc also present that we should have the cyanogen spectrum as well. Either, then, the first supposition is the true one, not disproving the presence of nitrogen, or else the atmosphere which the comet meets is hydrogen only, and contains no nitrogen."

The importance of the question here treated of comes out very well from these two extracts. We find the same spectral phenomenon at once called into court, and very properly called in, both to suggest the existence of chemical substances of which the chemist has never dreamt, and to explain the chemical nature of a large group of celestial bodies. ${ }^{1}$

There is little doubt that when a complete consensus of opinion is arrived at among the workers, other suggestions more far reaching still will be dcrived from the prosecution of these inquiries. For the present, however, the chief point to bear in mind is that both in line-spectra and in fluted spectra we have indications which I think favour the view that in each case the origin is compound rather than simple.

Oban, July 20

J. NORMAN LOCKYER

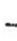

\section{THE EDUCATION DEBATE}

7 HE chorus of approval with which Mr. Mundella's report on the progress of elementary education was received on Monday cannot but be gratifying to all who have at heart the highest welfare of the country. With one or two unimportant exceptions-members whose vision is so bizarre as to discern communism in the cducation of the children of the working classes, and who connect the increase of weeds with the spread of education-what criticism there was referred to details of method. All the members whose opinions are of any weight agreed that vast good had resulted to the country by the working of the Code. As to the special subjects, among which science is included, the weight of opinion was decidedly in favour of their retention. The greatest friends of the Fourth Schedule will admit that there is still much room for improvement in the teaching of these subjects; it cannot be expected that so great a novelty in the system of elementary cducation in the country can all at once be taught to perfection. About the success of the compulsory system of education it may be said that the House was all but unanimous. The analogy between the treatment of

I With special reference to this last question, that of cometary spectra, one of acknowledged difficulty, I may perhaps be permitted to add here by way of note that the view I put forward some years ago touching the relation of this spectrum to that of the nebulæ has been lately strengthened spectrum of iron is that coincident with the "chief line "in the nebulaspecirum. 
paupers and the free education of the children of the working classes will not hold water. In the one case we are simply keeping from starvation people whose improvidence or misfortune have made them a dead burden on their fellows; in the other case we are feeding the minds of those who one day will have to bear the brunt of the work of the nation. The better these future workers are educated, the more intelligently and the more effectively are they likely to do their work, and the less likely are they to become inmates of our workhouses and prisons. As Serjeant Simon testified, even already is there a marked decrease of embryo criminals in our streets. The conclusion come to by Mr. Mundella and those who, like him, have the interests of education at heart, is not that we have gone too far, but that we have not gone far enough; not that we have reached finality, but that we have only made a good beginning. The figures he adduced to prove the success of the existing Education Act were practically admitted to be irrefutable; and we only trust the progress in the next ten years will be at an equal ratio to that achieved during the past decade. "Many of us," he truly said, "would pass away without seeing the full effect of the work we are doing." As to the propriety of encouraging the retention of exceptionally clever boys in elementary schools beyond the regulation age, the figures showed that it would be cruel and unjust to forbid this. Until we have a State system of secondary education in England similar to that about to be sanctioned in Scotland, until an equally decisive step is taken with regard to educational endowments in the one country as in the other, the nation would be doing a gross injustice to force exceptionally clever boys to leave school just when their intellects were beginning to shoot into full vigour. Mr. Mundella showed by his figures that Scotland is still ahead of England in the matter of education; that extra or special subjects are more widely sought after and with greater success, and that a larger percentage of children in elementary schools proceed to secondary education. But it should be remembered that this is the result of many generations of universal education, and that in Scotland it has long been considered as great a disgrace to be uneducated as in England it is considered to be immoral. There among the great majority of the working classes compulsory education was scarcely needed, and this will no doubt be the case in England in the course of a century or so, when education will have become as great a necessity as decent clothing. Again during the debate was it shown by those who have the best means of knowing that where science is properly taught there the children are as a rule more intelligent and bright, and better up in the ordinary subjects than in schools where science is neglected. Sir John Lubbock gave a remarkable instance of the favour with which properly conducted science-teaching is received by the children themselves:-

"He had lately," he said, "visited some of the Lambeth schools, and in one of the last he asked the children which subject they themselves preferred. Out of 229 children in the upper standards, 2 liked grammar best, II geography, 31 arithmetic, 38 history, and 147 elementary science. He did not quote this from any wish to exclude the other subjects, but because it seemed conclusive evidence against the proposal to omit elementary science.
He knew that many hon. members, when they thought of children learning these extra subjects, pictured to themselves anxious and weary children poring over a difficult and distasteful task. He wished they would go and see the reality-the bright, happy, intelligent faces of the children, and their delight as they found themselves able to answer the questions rapidly asked them by the master."

We have no intention of repeating the arguments we have so often adduced in favour of the teaching of at least such elementary science in our national schools as will be of practical use in after life and help to render the hard lives of the working classes brighter and nobler, and thus elevate the whole nation. The debate on Monday confirms all that has been adiduced in favour of such education, and is the best possible reply to the attack of Lord Norton in the Upper Ho use, an attack which the debate showed to be an anachronism. The whole tone of Mr. Mundella's address must convince all but the most prejudiced that the education of the country could not be in better or safer hands, and that he is not in the least likely to take any step that could be considered rash.

Quite in keeping with the tone of his Education address were his remarks in connection with the vote for the Science and Art Department. With regard to the vote of 4,00ol. for scientific research, Mr. Mundella said that it was expended under the advice of the Committee and members of the Royal Society, and that of the presidents of the various other scientific boclies. He thought the country could well afford to spend $5,000 \%$. on the matters that had been alluded to. "As it was we did not spend too much on science and art." This is a remarkable admission to make by our Minister of Science, for such the Vice-President of the Council is in reality if not in name. We do not wish a penny to be deducted from the grant for elementary education, which we hope to see gradually increased; indeed we would strongly urge Mr. Mundella to devote his energies, so long as he has opportunity, to perfecting the teaching of science in our elementary schools. When once a proper system is fairly established, there will be no danger of retrogression. -rapid progress will be certain. Not only so, but we are sure that the nation will be convinced that at the other end of the scale the neglect to encourage by national. funds scientific research is quite as disastrous to the highest welfare of the country as the neglect of elementary education. In Germany and France the national necessity of both is practically recognised, and they are both amply provided for. If Mr. Mundella is of opinion that we do not spend too much on science, that can only mean that the nation must suffer for this parsimony. It was admittedly as an experiment that the $4,000 l$. was added to the 1,000 l., which, by the by, but for the want of faith of the scientific nabobs of the time, might have been I0,000l., and that many years ago. Over and over again have we pointed out the benefit which the nation would reap from research when adequately encouraged, and that we can never hope to hold our own in this matter with foreign countries under existing conditions, in which some of our best men are compelled to waste their exceptional powers in teaching for the sake of bread and butter; while some among the "professors" whom in the view of some we were exclusively to look for research 
not only neglect research, but even their students in the most unblushing manner, in their greed of gold. We hope that when next Mr. Mundella has to ask for a vote for the Science and Art Department, he will present as strong a case for the encouragement of advanced science as he has done for the teaching of elementary science. The facts and figures in favour of the one are as strong as those in favour of the other.

\section{EUROPEAN CADDIS-FLIES}

A Monographic Revision and Synopsis of the Trichoptera of the European Fauna. By Robert McLachlan, F.R.S., F.L.S., \&c. (London: Van Voorst, I874I880.)

W OST persons have seen those curious aquatic insects 1 called caddis-worms, which live at the bottom of the water, protected by tubular cases formed of bits of stick, stones, sand, or shells, and are much used as bait by anglers; being, as Izaak Walton remarked, "a choice bait for the chub or chavender, or indeed for any great fish." It is also generally known that these caddis-worms are the larva or grubs of winged insects, known as caddisflies or water-moths, which abound in the vicinity of rivers or ponds and of ten fly into houses attracted by the light; but few persons except entomologists are aware that there arc nearly a hundred and fifty different species in the British Isles, while between four and five hundred are known from various parts of Europe--that they constitute a distinct order of insects, named "Trichoptera," from their hairy wings-and that they possess peculiarities of structure of the greatest interest as serving to connect, however imperfectly, such distinct and highly specialised orders, as the Hymenoptera and the Lepidoptera.

The perfect insects are characterised by four ample membranous wings, of which the hind pair are usually the largest, while the front pair are somewhat more leathery in texture. The wings are always more or less clothed with hair, sometimes to such an extent as to form a dense coat which completely hides the nervures; and it is this peculiar hairy covering which has given the name to the family. The neuration of the wings consists of longitudinal branching veins with a few cross veins forming cells, very different from the netted veins of most of the Neuroptera, with which the Trichoptera were formerly united, but bearing a considerable resemblance to those of some of the smaller moths. The body is also hairy, the legs long and spined, while the antennæ are usually longer than the body, slender and thread-like; and when the insect is in repose these are directed forward, and so closely pressed together as to appear like onc. The mouth is very small with quite rudimentary mandibles, and Mr. McLachlan thinlss that the insects usually take no nutriment whatever in the perfect state, "existing on the superabundant vitality acquired during their long larval stage," but he adds: "some of the larger species frequent flowers at night after the manner of moths, and are even attracted by the mixtures used by lepidopterists to attract their favourite insects, facts which prove that some, at any rate, partake of liquid nutriment." The exact mode in which this is effected is not yet clearly ascertained.
The eggs are gelatinous, and stick together in a mass which is attached to aquatic plants below the surface of the water, into which the female is said sometimes to enter for the purpose of depositing them in a proper situation. The cases formed by the larvæ are built up of various substances fastened together by silken threads spun from the mouth in the same manner as caterpillars spin thcir cocoons-another curious point of resemblance to the Lepidoptera. These cases vary greatly in the different families and genera, and though at present very imperfectly known it seems probable that every species has a distinctive form of case. The Phryganeidæ, for example make cylindrical cases of morsels of leaves or fibres arranged in a spiral manner, the cases are open at both ends, and it is believed that the larvæ have the power of turning in them. When about to change into a pupa the larva closes up the ends with vegetable matter and attaches the case to an aquatic plant. They live only in ponds, lakes, or marshes. Another family-the Limnophilidæ-have some genera which live in still, others in running waters, and their cases vary greatly, the most curious being those formed entirely of shells, often taken while their inmates are alive. Onc genus of this familyEnoicycla-is altogether anomalous, since the female has rudimentary wings and its larva lives in moss, often in woods far away from water, forming a case of fine sand intermixed with vegetable matter. One species is found in England. In the next family-Sericostomatidæ-the larvæ live generally in streams, forming cylindrical cases of sand or small stones, but sometimes the cases are broad and flattened, in others quadrangular, while in one genus-Helicopsyche-they are spiral, formed of sand grains, and often so closely resembling the shells of freshwater molluscs, that some of them have been described as species of Valvata, Paludina, \&c.! In the Hydropsychidæ and Rhyacophilidæ the larvæ are carnivorous, and form irregular cases of small stones fixed to larger stones at the bottom of the water, and sometimes several larva appear to live in company under a common covering of vegetable and other débris fastened together with silk. These are obliged to quit their retreats when wandering about in search of food, and they accordingly have the body and abdomen of a firmer consistency. The Rhyacophilida especially frequent torrents. Lastly, the Hydrophilidæ live in more or less seed-like, movable cases, formed of silk with minute sand-grains, and having a slit at each end forming two apertures, from either of which the larva can protrude its head. They are found among water-plants, on the surface of stones at the bottom of streams or ponds, and have the power of spinning a silken thread by which both the case and its inhabitant can float securely in the water. The insects produced from these larvæ are the smallest of the order, and often appear in great numbers.

When the larvæ of Trichoptera are about to change into pupe they close up the apertures of their cases either with a network of threads or with other materials, and some of them besides spin an inner cocoon. The pupæ, though quite motionless, bear a considerable resemblance to the perfect insect, the antennæ, legs, and wings being fully formed, but shorter, and all inclosed in separate sheaths and arranged on the breast. The head is however armed with a pair of strong horny hooks or jaws 